\title{
Citrus asymmetric somatic hybrids produced via fusion of gamma-irradiated and iodoacetamide-treated protoplasts
}

\author{
Claudine Maria de Bona( ${ }^{(1)}$, Jean Howe Gould ${ }^{(2)}$, J. Creighton Miller Jr( ${ }^{(3)}$, David Stelly ${ }^{(4)}$ and Eliezer Silva Louzada(5) \\ (1)Instituto Agronômico do Paraná, Rua Máximo João Kopp, oo 274, Bloco 1, Ala Sul, Centro Administrativo do Governo do Estado, Santa \\ Cândida, CEP 82630-900 Curitiba, PR, Brazil. E-mail: debona@iapar.br (2)Texas A\&M University (TAMU), Department of Ecosystem Science \\ and Management, College Station, Texas, USA, 77843-2138. E-mail: gould@tamu.edu ${ }^{(3)}$ TAMU, Department of Horticultural Sciences, College \\ Station Texas, USA, 77843. E-mail: jcmillerjr@tamu.edu (4)TAMU, Department of Soil \& Crop Sciences, College Station, Texas, USA, $77843-2474$. \\ E-mail: stelly@tamu.edu ${ }^{(5)}$ Texas A\&M University-Kingsville, Citrus Center, Weslaco, Texas, USA, 78599. E-mail: e-louzada@tamu.edu
}

\begin{abstract}
The objective of this study was to produce citrus somatic asymmetric hybrids by fusing gamma-irradiated protoplasts with iodoacetamide-treated protoplasts. Protoplasts were isolated from embryogenic suspension cells of grapefruit (Citrus paradisi Macfad.) cultivars Ruby Red and Flame, sweet oranges (C. sinensis Osbeck) 'Itaboraí', 'Natal', Valencia', and 'Succari', from 'Satsuma' (C. unshiu Marcow.) and 'Changsha' mandarin (C. reticulata Blanco) and 'Murcott' tangor (C. reticulata x C. sinensis). Donor protoplasts were exposed to gamma rays and receptor protoplasts were treated with $3 \mathrm{mmol} \mathrm{L}^{-1}$ iodoacetamide (IOA), and then they were fused for asymmetric hybridization. Asymmetric embryos were germinated, and the resulting shoots were either grafted onto sour orange, rough lemon or 'Swingle' (C. paradisi x Poncirus trifoliata) $\mathrm{x}$ 'Sunki' mandarin rootstock seedlings, or rooted after dipping their bases in indol-butyric acid (IBA) solution. The products were later acclimatized to greenhouse conditions. Ploidy was analyzed by flow cytometry, and hybridity was confirmed by amplified fragment length polymorphism (AFLP) analysis of plantlet DNA samples. The best treatment was the donor-recipient fusion combination of $80 \mathrm{~Gy}$-irradiated 'Ruby Red' protoplasts with 20 min IOA-treated 'Succari' protoplasts. Tetraploid and aneuploid plants were produced. Rooting recalcitrance was solved by dipping shoots' stems in 3,000 $\mathrm{mg} \mathrm{L}^{-1} \mathrm{IBA}$ solution for $10 \mathrm{~min}$.
\end{abstract}

Index terms: Citrus sp., gamma irradiation, grapefruit, protoplast fusion, somatic hybridization, sweet orange.

\section{Híbridos somáticos assimétricos de citros produzidos pela fusão de protoplastos irradiados e tratados com iodoacetamida}

Resumo - O objetivo deste trabalho foi produzir híbridos somáticos assimétricos de citros pela fusão de protoplastos irradiados com raios gama e protoplastos tratados com iodoacetamida. Protoplastos foram isolados de suspensões celulares embriogênicas de pomelo (Citrus paradisi Macfad.), cultivares Ruby Red e Flame, de laranja doce (C. sinensis Osbeck) 'Itaboraí', 'Natal', Valencia' e 'Succari', de tangerinas 'Satsuma' (C. unshiu Marcow.) e 'Changsha' (C. reticulata Blanco) e de tangor 'Murcott' (C. reticulata $\mathrm{x} C$. sinensis). Protoplastos doadores foram expostos a raios gama e protoplastos receptores foram tratados com $3 \mathrm{mmol} \mathrm{L}^{-1}$ de iodoacetamida (IOA) e fusionados para hibridação assimétrica. Embriões assimétricos foram germinados e as brotações produzidas foram enxertadas sobre porta-enxertos de sementes de 'Laranja azeda', 'Limão rugoso' ou citrumelo 'Swingle' (C. paradisi x Poncirus trifoliata) x 'Sunki' ou enraizadas após embebição em solução de ácido indol-3-butírico (IBA) e aclimatadas em casa de vegetação. A análise de ploidia foi realizada por meio de citometria de fluxo e a hibridicidade foi confirmada por análise de polimorfismo de comprimento de fragmentos amplificados (AFLP) de amostras de DNA das plântulas. A melhor combinação doador-recipiente foi de protoplastos de 'Ruby Red' irradiados com 80 Gy, fusionados com protoplastos de 'Succari' tratados por 20 min com IOA. Plantas tetraploides e aneuploides foram produzidas e o problema de recalcitrância ao enraizamento foi resolvido pela introdução das bases das brotações em $3.000 \mathrm{mg} \mathrm{L}^{-1}$ de IBA por 10 min.

Termos para indexação: Citrus sp., irradiação gama, pomelo, fusão de protoplasto, hibridação somática, laranja doce.

\section{Introduction}

Sexual hybridization in most citrus species is very complicated. Sterility, sexual incompatibility, heterozygosity, nucellar embryony (Davies \& Albrigo, 1994; Ollitrault et al., 2000; Louzada et al., 2002) and polyembryony may impair creation of large segregating populations for selection (Grosser \&

Pesq. agropec. bras., Brasília, v.44, n.5, p.454-462, maio 2009 
Gmitter Junior, 1990). Somatic hybridization via protoplast fusion, on the other hand, is a powerful tool in genetic breeding because it circumvents such sexual restraints (Grosser \& Gmitter Junior, 2005).

Somatic hybridization has contributed tremendously to citrus improvement and many citrus somatic hybrids have been reported to be in use in various breeding programs (Gloria et al., 2000; Calixto, 2004). Even though symmetric somatic hybrids have great potential for rootstock improvement and as tetraploid breeding parents in interploid crosses, they may not have direct application as scion cultivars as they may present complex genetic constitution. Asymmetric somatic hybridization (donor-recipient fusion) using $\mathrm{X}$ - or $\gamma$-irradiation, on the other hand, has great potential for scion improvement because it allows partial genomic transfer (Rasmussen et al., 2000) as chromosome elimination is induced by high radiation doses. Furthermore, colony formation of irradiated cells tends to be avoided (Derks et al., 1992).

Cell colony formation is also affected by iodoacetamide (IOA), an irreversible inhibitor of enzymes involved in glycolysis (Epstein et al., 1981). IOA-treated cells cannot divide and eventually degenerate (Bonnema \& O'Connell, 1990). Fusion of irradiated protoplasts with IOA-treated protoplasts facilitates hybrids selection, since only hybrid cells are able to develop due to genome complementation (Tian et al., 2002).

Asymmetric hybridization has much yet to be explored. Vardi et al. (1989) have used it to produce cybrids. However, the first and only report on regeneration of citrus mixoploid hybrid plants via protoplast asymmetric fusion was published by Liu \& Deng (2002), who produced hybrids from 'Dancy' tangerine and 'Page' tangelo by using $\mathrm{X}$-rays, yet plantlets were recalcitrant to root.

The objective of this study was to produce citrus somatic asymmetric hybrids via protoplast fusion by using gamma-irradiated protoplasts combined to IOA-treated protoplasts.

\section{Materials and Methods}

Protoplasts were isolated from habituated embryogenic suspension cells of grapefruit (Citrus paradisi Macfad.) cultivars Ruby Red and Flame, sweet oranges (C. sinensis Osbeck) 'Itaboraí', 'Natal', Valencia' and 'Succari', 'Satsuma' (C. unshiu Marcow.) and 'Changsha' (C. reticulata Blanco) mandarin and 'Murcott' tangor (C. reticulata $\mathrm{x}$ C. sinensis). Suspension cells from ovule-derived embryogenic callus were maintained in a two-week subculture cycle in liquid half-strength $\mathrm{H}+\mathrm{H}$ medium (Grosser \& Gmitter Junior, 1990) under constant agitation on a horizontal gyratory shaker (Lab-Line Instruments, Inc., Melrose Park, IL, USA) at $130 \mathrm{rpm}$, at room temperature and under constant illumination (about 500 lux).

Protoplast isolation followed Grosser \& Gmitter Junior (1990) protocol with the following modifications. Approximately $1 \mathrm{~g}$ of fresh weight drained cells (four to ten days after subculturing) was placed in a $5 \mathrm{~cm}$ diameter Petri dish (BD Falcon, Flanklin Lakes, NJ, USA). Cells were digested overnight, in the dark, on a rocker platform (Bellco Glass, Inc, Vineland, NJ, USA) with six oscillations per minute. To improve protoplast isolation, different ratios from 0.5 to $1 \mathrm{~mL}$ of enzyme solution plus 4 to $5 \mathrm{~mL}$ of 0.4 to $0.7 \mathrm{~mol} \mathrm{~L}^{-1}$ BH3 medium were added in order to find the best enzyme:BH3 medium combination and molarity. For cell lines whose protoplasts were difficult to isolate, a two-step digestion was performed. The enzyme solution consisted of $1 \%$ cellulase $\mathrm{R}-10,0.2 \%$ pectolyase Y-23, 1\% macerozyme R-10 (all enzymes from Karlan, Santa Rosa, CA, USA), $0.024 \mathrm{~mol} \mathrm{~L}^{-1}$ $\mathrm{CaCl}_{2}, 0.92 \mathrm{mmol} \mathrm{L} \mathrm{L}^{-1} \mathrm{NaH}_{2} \mathrm{PO}_{4}, 6.15 \mathrm{mmol} \mathrm{L} \mathrm{L}^{-1}$ 2-[N-morpholino]ethanesulfonic acid (MES) (Sigma, Dallas, TX, USA), and 0.4 to $0.7 \mathrm{~mol} \mathrm{~L}^{-1}$ of mannitol. The $\mathrm{pH}$ was adjusted to 5.6, and the solution was filter-sterilized.

Donor protoplasts were exposed to gamma ray doses of 30, 50, 70, 80, 100, 150, 200 and 300 Gy at the United States Department of Agriculture, Animal and Plant Health Inspection Service, Moore Air Base, Edinburg, TX, USA. Receptor protoplasts were treated with $3 \mathrm{mmol} \mathrm{L}^{-1}$ iodoacetamide (IOA) (Sigma, Dallas, TX, USA) for 10, 15 or 20 min (Bonnema \& O'Connell, 1990). The treatments applied to donor and receptor genomes (Gy + IOA) had the objective of accomplishing double genome inactivation, i.e. inactivation of both donor and receptor genomes, to facilitate hybrid selection since only hybrid cells could further develop by genome complementation. Protoplasts were washed with liquid $0.6 \mathrm{~mol} \mathrm{~L}^{-1} \mathrm{BH} 3$ medium and centrifuged for $5 \mathrm{~min}$ at $100 \mathrm{~g}_{\mathrm{n}}$. The pellet was re-suspended in fresh liquid $0.6 \mathrm{~mol} \mathrm{~L}^{-1} \mathrm{BH} 3$ medium.

Fusions of IOA-treated protoplasts with irradiated protoplasts; fusions of non-IOA-treated protoplasts 
with irradiated protoplasts, and non-IOA-treated with non-irradiated protoplasts (standard protoplast fusion) were performed. Irradiated protoplast and IOA-treated protoplasts were plated as controls.

Donor-receptor combinations (Table 1) were randomly chosen. Each fusion combination was performed one to three times producing at least ten plates in each fusion.

The fused protoplast culture followed the Grosser \& Gmitter Junior (1990) protocol. The fused protoplasts were cultured in six drops of $0.6 \mathrm{~mol} \mathrm{~L}^{-1} \mathrm{BH} 3$ with 12 drops of the same medium added at the edge of the plate to avoid protoplast desiccation. Osmolarity of the culture medium was gradually reduced by adding three to four drops of 1:1:1 (0.6 mol L-1 BH3:EMEP:EME) and later 1:2 liquid media (0.6 mol L $\mathrm{L}^{-1} \mathrm{BH}$ :EME). Microcalli colonies were transferred to solid EME medium and gradually exposed to light. The whole process (protoplast isolation, fusion, cell wall formation, and cell division) was monitored under a Nikon Eclipse TE300 inverted microscope (Nikon Instruments Inc. Melville, NY, USA) and lens Nikon Plan Fluor ELWD 20X/0.45 Ph1 DM, or Nikon Plan Fluor ELWD 40X/0.6 Ph2 DM (both with correction collar). Images were captured by using the Image-Pro Plus software version 4.5.1 in a CoolSNAP-PROcf camera (Media Cybernetics, Silver Spring, MD, USA). Formed embryos were transferred and subcultured on fresh solid EME media until they reached approximately $0.5 \mathrm{~cm}$, then transferred to EME 1500 media (Grosser \& Gmitter Junior, 1990) for further development.

Embryos were transferred to B+ embryo germination medium (Grosser \& Gmitter Junior, 1990) for shoot formation. Proliferating embryos and embryos presenting shoots were transferred to Magenta boxes (Magenta Corp., Chicago, IL, USA) containing B+ with $0.01 \mathrm{mg} \mathrm{L}^{-1}$ of NAA. Developed shoots were excised and transferred to Magenta boxes containing RMAN rooting medium (Grosser \& Gmitter Junior, 1990), and further grafted onto 12 to $17 \mathrm{~cm}$ high sour orange, rough lemon, C-22 or C-146 ['Swingle' trifoliate orange (P. trifoliata) x 'Sunki' mandarin] rootstock seedlings. Grafted shoots were covered with plastic bag to protect from desiccation and placed in a growth room for acclimatization until transference to greenhouse; or dipped in 1,000 $\mathrm{mg} \mathrm{L}^{-1}$ 1-naphthalene-acetic acid (NAA) for $5 \mathrm{~min}$ or $3,000 \mathrm{mg} \mathrm{L}^{-1}$ indol-butyric acid (IBA) for 3, 5, 7 or $10 \mathrm{~min}$, and placed in EME with
$6 \%$ sucrose for rooting. Rooted plantlets were planted in jiffy pots (Jiffy Products, Shippagan, CA, USA) or plastic pots with commercial mix, covered by plastic bags, and placed in a growth room for acclimatization and then transferred to the greenhouse.

DNA was isolated from callus or suspension cells of parental species and from leaves of regenerated plantlets using DNeasy Plant Mini kit (Qiagen, Valencia, CA, USA) with minor modifications. Calli and drained suspension cells were ground in liquid nitrogen until a paste was formed. Approximately $100 \mathrm{mg}$ of the paste was put inside a sterile $2 \mathrm{~mL}$ microfuge tube with $400 \mu \mathrm{L}$ of buffer AP1 and $8 \mu \mathrm{L}$ of RNase A stock solution $\left(100 \mathrm{mg} \mathrm{mL}^{-1}\right)$. Tubes were incubated at $37^{\circ} \mathrm{C}$ over a rocker platform for $30 \mathrm{~min}$ plus $10 \mathrm{~min}$ at $65^{\circ} \mathrm{C}$.

Table 1. Formation of shoots or plantlets on irradiated protoplast control, on somatic symmetric and asymmetric protoplast fusion combinations. Number of surviving plants in bold, number of grafted $(G)$, rooted $(R)$, acclimatized (AC) and analyzed for ploidy - aneuploid (A), diploid (D) or tetraploid $(\mathrm{T})$ - shoots.

\begin{tabular}{|c|c|}
\hline Cultivars & Shoots or plantlets acquired \\
\hline \multicolumn{2}{|c|}{ Irradiated protoplast (Grays) control } \\
\hline Itaboraí (100) & $4,2 \mathrm{G}, 2 \mathrm{R}, 1 \mathrm{AC}, 1 \mathrm{D}$ \\
\hline \multicolumn{2}{|c|}{ Protoplast + protoplast fusion ${ }^{(1)}$} \\
\hline Ruby Red + Itaboraí & $\mathbf{2 3}, 8 \mathrm{G}, 15 \mathrm{R}, 9 \mathrm{AC}, 2 \mathrm{D}$ \\
\hline \multicolumn{2}{|c|}{ Protoplast + irradiated protoplast fusion $(\text { Grays })^{(2)}$} \\
\hline Ruby Red + Succari (100) & $>7^{(3)}$ \\
\hline Ruby Red + Itaboraí (100) & $>\mathbf{1 0} *, 10 \mathrm{G}, 3 \mathrm{AC}, 1 \mathrm{~A}$ \\
\hline Itaboraí + Ruby Red (100) & $>\mathbf{5}^{(3)}$ \\
\hline \multicolumn{2}{|c|}{$\begin{array}{c}3 \mathrm{mmol} \mathrm{L}^{-1} \text { iodoacetamide-treated protoplast }(\mathrm{min})+\text { irradiated protoplas } \\
\text { fusion }(\text { Grays })^{(4)}\end{array}$} \\
\hline Ruby Red (20) + Succari (30) & $\mathbf{1}, 1 \mathrm{G}, 1 \mathrm{AC}$ \\
\hline Ruby Red (20) + Succari (100) & $>\mathbf{1 0}{ }^{(3)}, 5 \mathrm{G}, 3 \mathrm{AC}$ \\
\hline Ruby Red (20) + Itaboraí (100) & $\mathbf{1}, 1 \mathrm{G}, 1 \mathrm{AC}$ \\
\hline Ruby Red (20) + Succari (80) & $>\mathbf{3 9}^{(3)}, 10 \mathrm{G}, 29 \mathrm{R}, 31 \mathrm{AC}, 13 \mathrm{~T}$ \\
\hline Ruby Red (15) + Itaboraí (100) & $\mathbf{1}, 1 \mathrm{G}, 1 \mathrm{AC}$ \\
\hline Ruby Red (15) + Itaboraí (30) & 3 \\
\hline Murcott $(20)+$ Natal $(100)$ & $\mathbf{1}, 1 \mathrm{G}$ \\
\hline $\operatorname{Murcott}(20)+$ Itaboraí (100) & $\mathbf{1}, 1 \mathrm{G}$ \\
\hline Itaboraí $(15)+$ Murcott (50) & $2,1 \mathrm{R}, 1 \mathrm{G}, 1 \mathrm{AC}$ \\
\hline
\end{tabular}

${ }^{(1)}$ Cultivars Ruby Red + Succari, Ruby Red + Natal, Ruby Red + Valencia, Flame + Succari, Flame + Natal, Flame + Itaboraí did not survive. ${ }^{(2)}$ Cultivars Ruby Red + Natal 100 Gy, Ruby Red + Natal (150), Ruby Red + Itaboraí (150), Ruby Red + Natal (80), Ruby Red + Murcott (70), Ruby Red + Natal (70), Flame + Itaboraí (100), Flame + Natal (100), Flame + Succari (100), Natal + Ruby Red (150) did not survive. ${ }^{(3)}$ Many other shoots were being produced when the counting stopped. ${ }^{(4)}$ Cultivars Ruby Red (20) + Succari (150), Ruby Red (20) + Natal (100), Ruby Red (20) + Natal (200), Ruby Red (20) + Natal (300), Ruby Red (20) + Succari (150), Ruby Red (20) + Natal (50), Ruby Red (20) + Itaboraí (80), Ruby Red (15) + Murcott (100), Ruby Red (15) + Succari (100), Ruby Red (15) + Natal (100), Ruby Red (15) + Natal (50), Ruby Red (15) + Succari (50), Ruby Red (15) + Murcott (30), Ruby Red (10) + Natal (50), Ruby Red (10) + Murcott (50), Murcott (15) + Succari (50), Murcott (10) + Itaboraí (100), Natal (15) + Ruby Red (50), Natal (20) + Murcott (100) did not survive. 
Tubes were mixed three times during incubation. From this point, extraction followed the kit protocol.

Analyses of ploidy were performed by flow cytometry in 0.5 to $1 \mathrm{~cm}$ leaves, using a Partec ploidy analysis instrument (D-48161, Münster, Germany), at the Citrus Research and Education Center, University of Florida, Lake Alfred, USA, following the method reported by Miranda et al. (1997).

To confirm hybridity, DNA samples were analyzed by amplified fragment length polymorphism (AFLP), performed in a 4300 DNA analyzer (Li-Cor, Inc. Lincoln, NE, USA) using the IRDye Fluorescent AFLP Kit (Li-Cor Biosciences, Lincoln, NE, USA) with few modifications. Briefly: for restriction digestion of genomic DNA, $100 \mathrm{ng}$ of template DNA in less than $9 \mu \mathrm{L}$ were used, plus $1 \mu \mathrm{L}$ of $E c o \mathrm{RI} / M s e \mathrm{I}$ enzyme mix [1.25 units $\mu \mathrm{L}^{-1}$ each in $10 \mathrm{mmol} \mathrm{L}^{-1}$ Tris- $\mathrm{HCl}$ ( $\mathrm{pH} 7.4$ ), $50 \mathrm{mmol} \mathrm{L}^{-1} \mathrm{NaCl}, 0.1 \mathrm{mmol} \mathrm{L}^{-1}$ EDTA, $1 \mathrm{mmol} \mathrm{L}^{-1}$ DTT, $200 \mu \mathrm{g} \mathrm{mL}^{-1}$ BSA 50\% (v/v) glycerol, 0.15\% Triton X-100], $2.5 \mu \mathrm{L} 5 \mathrm{X}$ reaction buffer $\left[50 \mathrm{mmol} \mathrm{L}^{-1}\right.$ Tris- $\mathrm{HCl}(\mathrm{pH} 7.5), 50 \mathrm{mmol} \mathrm{L}^{-1}$ magnesium-acetate, $250 \mathrm{mmol} \mathrm{L}^{-1}$ potassium-acetate] were combined and deionized water was added to $12.5 \mu \mathrm{L}$ total volume and incubated at $37^{\circ} \mathrm{C}$ for 2 hours. The enzyme was inactivated at $70^{\circ} \mathrm{C}$ for $15 \mathrm{~min}$ and placed on ice. Adapter ligation was performed by adding to the previous solution $12 \mu \mathrm{L}$ of adaptor mix [EcoRI/MseI adapters, $0.4 \mathrm{mmol} \mathrm{L}^{-1}$ ATP, $10 \mathrm{mmol} \mathrm{L}^{-1}$ Tris- $\mathrm{HCl}$ (pH 7.5) $10 \mathrm{mmol} \mathrm{L}^{-1}$ magnesium-acetate, $50 \mathrm{mmol} \mathrm{L}^{-1}$ potassium-acetate], $0.5 \mu \mathrm{L}$ of $\mathrm{T} 4$ DNA ligase and incubating the mixture at $20^{\circ} \mathrm{C}$ for 2 hours. Ten microliters of the mixture were diluted $1: 10$ by adding $90 \mu \mathrm{L}$ of TE buffer [10 mmol L-1 Tris- $\mathrm{HCl}(\mathrm{pH} 8.0)$, $1.0 \mathrm{mmol} \mathrm{L}^{-1}$ EDTA]. Pre-amplification was performed by adding $2.5 \mu \mathrm{L}$ of the 1:10 diluted ligation mixture to a $0.2 \mathrm{~mL}$ PCR tube containing $20 \mu \mathrm{L}$ of AFLP Pre-amp primer mix, $2.5 \mu \mathrm{L}$ of $10 \times$ PCR reaction buffer [100 mmol L-1 Tris- $\mathrm{HCl}$ (pH 8.3), 15 mmol L $\mathrm{mgCl}_{2}$, $500 \mathrm{mmol} \mathrm{L}^{-1} \mathrm{KCl}$, and $0.5 \mu \mathrm{L}$ Taq DNA polymerase (2.5 units $\mu \mathrm{L}^{-1}$ ) (Roche Molecular Biochemicals, Indianapolis, IN, USA). Thirty cycles at $94^{\circ} \mathrm{C}$ for $30 \mathrm{sec}$, $56^{\circ} \mathrm{C}$ for $1 \mathrm{~min}$ and $72^{\circ} \mathrm{C}$ for $1 \mathrm{~min}$ were performed. MseI primers used for selective amplification were from MWG (MWG Biotech AG, Ebersberg, Germany) and Operon (Operon Biotechnologies, Inc., Huntsville, AL, USA). For selective amplification, $2 \mu \mathrm{L}$ of pre-amplified DNA, $1.96 \mu \mathrm{L}$ of nuclease free water, $1 \mu \mathrm{L}$ of $10 \times$ buffer (Promega Corporation, Madison, WI,
USA), $1 \mu \mathrm{L}$ of $25 \mathrm{mmol} \mathrm{L}^{-1} \mathrm{MgCl}, 1 \mu \mathrm{L}$ of $2 \mathrm{mmol} \mathrm{L}^{-1}$ dNTPs, $0.04 \mu \mathrm{L}$ of Taq polymerase $\left(5\right.$ units $\left.\mu \mathrm{L}^{-1}\right), 2 \mu \mathrm{L}$ of MseI primer and $0.5 \mu \mathrm{L}$ of both 700 and 800 IRDye EcoRI primer were used. One cycle of $94^{\circ} \mathrm{C}$ for $30 \mathrm{sec}$, $65^{\circ} \mathrm{C}$ for $30 \mathrm{sec}$, and $72^{\circ} \mathrm{C}$ for $1 \mathrm{~min} ; 12$ cycles of $94^{\circ} \mathrm{C}$ for $30 \mathrm{sec}, 65^{\circ} \mathrm{C}$ for $30 \mathrm{sec}$, and $72^{\circ} \mathrm{C}$ for $1 \mathrm{~min}$; and 23 cycles of $94^{\circ} \mathrm{C}$ for $30 \mathrm{sec}, 65^{\circ} \mathrm{C}$ for $30 \mathrm{sec}$, and $72^{\circ} \mathrm{C}$ for $1 \mathrm{~min}$ were performed. After amplification $2 \mu \mathrm{L}$ of the samples were diluted with $8 \mu \mathrm{L}$ of nuclease-free water and $5 \mu \mathrm{L}$ of dye (Li-Cor). Samples and ladder (Li-Cor) were denatured for $3 \mathrm{~min}$ at $94^{\circ} \mathrm{C}$ and placed on ice. Each sample $(0.5 \mu \mathrm{L})$ was loaded on a 96 -well polyacrylamide gel and image data was viewed and printed using Saga (Li-Cor) software. AFLP to locate polymorphisms among donor and receptor genomes ('Ruby Red', 'Itaboraí', 'Succari', and 'Murcott') and AFLP comparing donor and receptor samples with the hybrid candidate samples were performed. MseI unlabeled/EcoRI labeled primer combinations were, respectively: $\mathrm{CAA}+\mathrm{ACA}, \mathrm{AGG}$ or $\mathrm{ACT}, \mathrm{CT}+\mathrm{ACT}$, ACA or ACG and CA + AGG, ACC, ACT or ACA. Polymorphic bands were observed by naked eye. Saga software and screen amplifications confirmed score of not so visible bands.

\section{Results and Discussion}

Proportions of enzyme solution to $\mathrm{BH} 3$ medium as well as molarity had to be adjusted for each cultivar during protoplast isolation. The best $0.6 \mathrm{mmol} \mathrm{L}^{-1}$ BH3:enzyme solution combination for 'Ruby Red' was 3:1; for 'Flame', 'Natal' and 'Satsuma' it was 4:0.5, and for 'Murcott' and 'Changsha' it was 3:0.5 of $0.7 \mathrm{mmol} \mathrm{L}^{-1}$ BH3:enzyme solution. Sucrose $35 \%$ had to be used in order to form the protoplasts band in 'Natal' because of the high starch content present in the cells. However, protoplast breakage was more common.

Some of the cultivars were less amenable to conventional digestion methods, which yielded undesirable mixtures of under-digested cell clumps and over-digested cells in the same plate, often in combination with considerable amounts of cell bursting. Cells from the cultivars Itaboraí and Succari were incubated in 2:0.5 $\mathrm{BH} 3$ medium: $1 \%$ macerozyme solution on a shaker at $6 \mathrm{rpm}$, for 2 hours. Then, 2:0.5 of $\mathrm{BH} 3$ medium: $1 \%$ cellulose and $0.2 \%$ pectolyase enzyme solution were added to the plates. For the Valencia cultivar, 2:0.25 was added to pre-digest the 
cells, and two hours later, 3:0.25 was added. This gradual digestion was very efficient for the above problematic cultivars and good numbers of protoplasts were isolated. A possible explanation is that the pre-digestion lead to a better separation of the cells. Cellulase is a cellulose-digesting enzyme, and pectolyase, a pectin breaker (Fang et al., 2006). The use of macerozyme may have promoted a more efficient infiltration of the cellulose/pectolyase solution.

In general, most cultivars yielded an adequate number of protoplasts. 'Valencia' and 'Natal' however presented high content of starch and protoplasts breakage. Protoplasts usually stayed in the bottom of the flask and bands of protoplasts were not easily formed. Cultivars with high starch content are known to be less amenable to protoplast isolation, and it is known that no starch or few starchy cells usually yield much higher protoplast numbers (Crowder et al., 1979). The process of protoplast isolation per se is a highly stress-inducing procedure, which may cause more damage in cells with high content of starch (Papadakis et al., 2002). 'Valencia' was the most recalcitrant genotype for protoplast isolation and it was excluded from this study.

Cultivars also responded differently to irradiation. 'Itaboraí' seemed to be the most resistant against irradiation since a few shoots regenerated from the 100 Gy-irradiated protoplast control. However, few escapes are normal and irradiation doses similar or below should be applied since in mutation breeding a dose that results in 50\% plant survival is generally used. In $\gamma$-irradiated lotus, for example, no survival was observed at $60 \mathrm{~Gy}, 50 \%$ of survival at $20 \mathrm{~Gy}$, while mutants were formed with 30 Gy (Arunyanart \& Soontronyatara, 2002). Doses of 150 Gy and higher were lethal to all cultivars in this study. Such dose probably caused fragmentation and subsequent elimination of chromosomes leading to a complete division-arrest. Liu \& Deng (2002) observed a dose-dependent inhibitory impact on the regeneration of citrus hybrid shoots treated with X-rays. Derks et al. (1992) observed some cell division in tomato protoplast when using $50 \mathrm{~Gy}$ but cell division was completely prevented after $100 \mathrm{~Gy}$.

Tolerance to irradiation varied among the tested varieties and none survived exposure to $150 \mathrm{~Gy}$ and above gamma rays. It is important to observe the limit dose which protoplasts of a variety can be exposed to in order to provide great amount of asymmetry without jeopardizing the recovery of the treated protoplasts. The fusions involving irradiated 'Satsuma' protoplasts ('Ruby Red' + 'Satsuma' 150 Gy; IOA-20 min 'Ruby Red' + 'Satsuma' 200 Gy; 'Flame' + 'Satsuma' 100 Gy; 'Flame'+ 'Satsuma' 150 Gy; IOA-20 min 'Ruby Red' + 'Satsuma' 150 Gy, IOA-20 min 'Ruby Red' + 'Satsuma' 200 Gy) did not form embryos; fusions involving irradiated 'Flame' protoplasts (IOA-20 min 'Flame' + 'Natal' 150 Gy; IOA-20 min 'Flame' + 'Succari' 100 Gy; IOA-20 min 'Flame' + 'Itaboraí' 150 Gy) did not develop further than the embryo stage; fusions involving irradiated 'Changsha' (IOA-10 min 'Ruby Red' + 'Changsha' 50 Gy; IOA-15 min 'Ruby Red' + 'Changsha' 100 Gy) did not form embryos. 'Ruby Red' + 'Itaboraí' 100 Gy produced more than 10 shoots and 'Ruby Red' + Succari' 100 Gy more than seven shoots, while 'Itaboraí' + 'Ruby Red' 100 Gy produced more than five shoots (Table 1). Unfortunately, most shoots were lost during media optimization, rooting tentative with rooting medium and NAA, and acclimatization.

The four 'Itaboraí' 100 Gy escape (irradiated protoplast control) plantlets were grafted or induced to root. However, they were weak and three of them died. The surviving grafted shoot was found to be diploid by flow cytometry analysis. No other survival was observed on irradiated protoplast controls ('Itaboraí' 150 Gy; 'Murcott' 50 and 100 Gy; 'Succari' 80, 100 and 150 Gy).

While some escapes happened in the irradiated protoplast controls, $3 \mathrm{mmol} \mathrm{\textrm {L } ^ { - 1 }}$ of IOA totally inhibited further development of protoplasts (IOA-10, 15 and 20 min 'Ruby Red', IOA-15 min 'Itaboraí'; IOA-20 min 'Natal'), which did not recover and burst (Figure 1). Ge et al. (2006), in order to abolish nursing effect, used 2-4 mmol L-1 IOA dose for $15 \mathrm{~min}$ and observed complete growth inhibition of both wheat and Italian ryegrass protoplasts. One $\mathrm{mmol} \mathrm{L}^{-1}$ of IOA for $20 \mathrm{~min}$ at $4^{\circ} \mathrm{C}$ was not sufficient to prevent cell division in chicory protoplasts but $2-4 \mathrm{mmol} \mathrm{L}^{-1}$ completely inhibited protoplast division (Varotto et al., 2001). Furuta et al. (2004) used 5 mmol L-1 IOA for $10 \mathrm{~min}$ at $4^{\circ} \mathrm{C}$, to inactivate chrysanthemum protoplasts before fusing it with wormwood.

Cell division and multiplication were different in the IOA-treated protoplast and irradiated protoplast controls and the fused cells, showing the efficiency of the fused treatments. While IOA-treated protoplast control cells could not divide and degenerated 
(Figure $2 \mathrm{~A}$ ), division in irradiated protoplast control cells was delayed (Figure 2 B). Fused protoplasts, nevertheless, divided, multiplied and formed microcalli (Figure 2C), probably due to genome complementation. Hence, the process of hybrid cell selection was made easier and more efficient. Grosser \& Gmitter Junior (1990) suggested that the process of fusion itself might trigger initiation of somatic embryogenesis. No extra time and material were spent with irradiated protoplast and IOA-treated protoplast controls. It was the first time that the combination of irradiation and IOA to inactivate both donor and receptor genomes was used in citrus and may be considered a very efficient method for hybrid selection and hybridity confirmation, since non-hybrid cells cannot develop. Previously, Tian et al. (2002) had expedited the selection of highly asymmetric hybrids of Medicago truncatula + M. rugosa and M. truncatula + M. scutellata by treating the receptor protoplasts with IOA and irradiating the donor protoplasts.

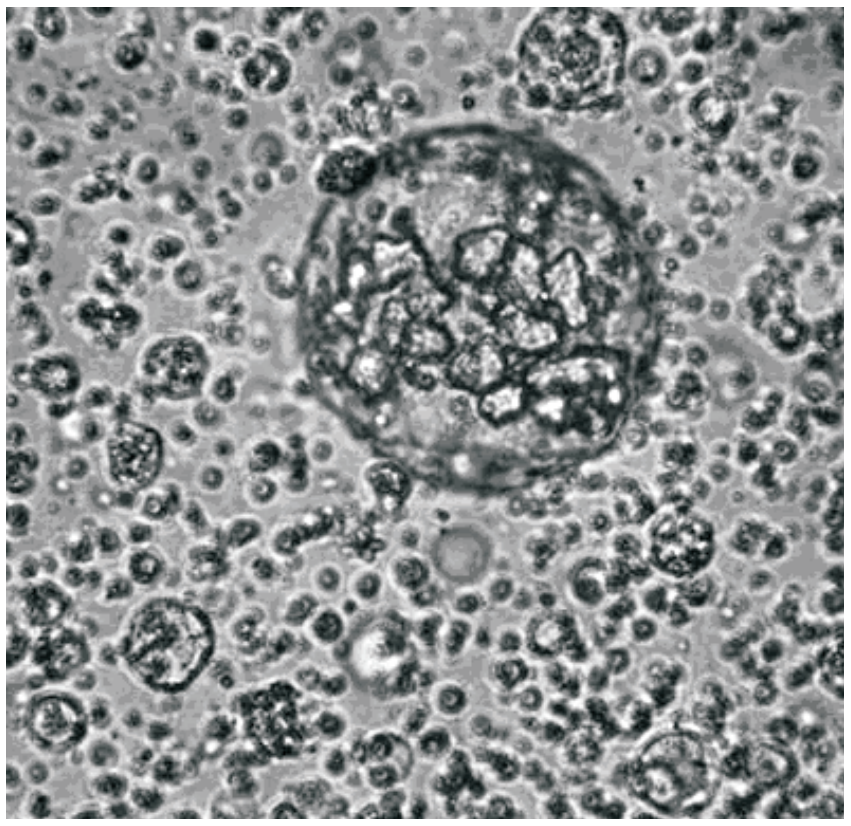

Figure 1. Iodoacetamide (IOA) treated 'Ruby Red' protoplast showing cell disintegration and debris of burst IOA treated protoplasts. Photography taken under a Nikon Eclipse TE300 inverted microscope using Nikon Plan Fluor ELWD 40 X/0.6 Ph2 DM lent with correction collar.

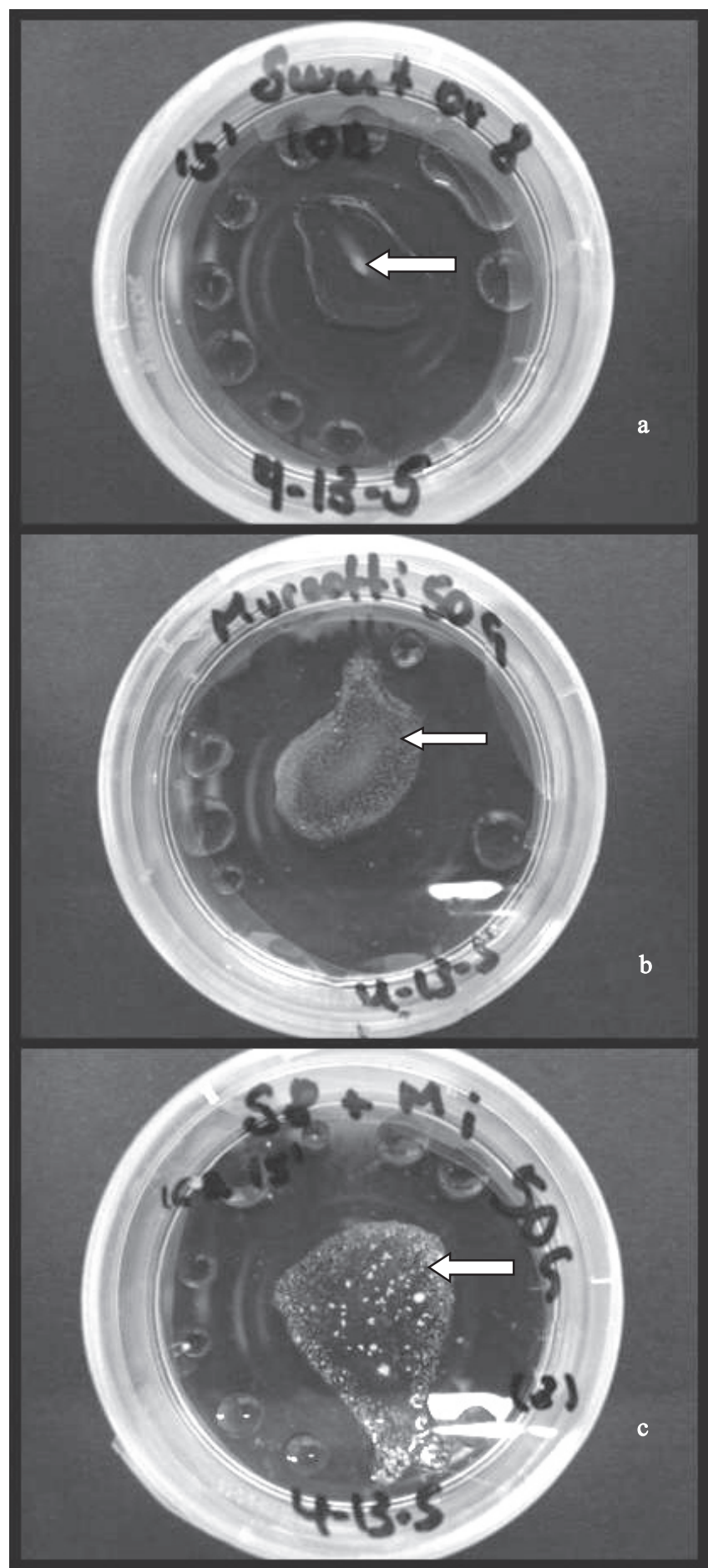

Figure 2. Top to bottom: iodoacetamide (IOA)-treated 'Itaborai' protoplasts floating in EME medium drops, still in the middle of the plate, showing no growth; irradiated 'Murcott' protoplasts which formed cell wall and grew a little but formed no microcalli; IOA-treated 'Itaborai' with irradiated 'Murcott' fused protoplasts which formed microcalli due to genome complementation. 
Rooting of putative asymmetric hybrid plantlets could not be accomplished in RMAN rooting media and many shoots were grafted onto seedling rootstocks. However, the process was time consuming and skill dependent. Liu \& Deng (2002), the first to produce citrus mixoploid asymmetric hybrid shoots, also observed that shoots were recalcitrant to root, even when placed in the rooting media.

The rooting problem was solved by dipping regenerated shoots' stems in $3,000 \mathrm{mg} \mathrm{L}^{-1}$ IBA solution for $10 \mathrm{~min}$ and placing them in magenta boxes containing EME medium with 6\% sucrose. The process was so successful (Figure 3) that roots emerged from any wounded part of the stem in contact with the auxin solution, showing that latent or preformed root initials in stems lie dormant and develop if properly stimulated (Hartmann et al., 1997).

The IOA-15 min 'Itaboraí' + 'Murcott' 50 Gy fusions produced one shoot (named Z5) which rooted but did not survive acclimatization, and the IOA-20 min 'Murcott' + 'Natal' 100 Gy fusion produced also one shoot (named Z10) which was grafted onto C-22 rootstock. AFLP analysis from both shoots showed bands from both parents with MseI-CT plus EcoRI-ACT, MseI-CAA plus EcoRI-AGG, and MseI-AC plus EcoRI-ACT primer combinations (Figure 4).

In AFLP performed to identify polymorphisms among donor and receptor genomes ('Ruby Red', 'Itaboraí', 'Succari', and 'Murcott'), very similar AFLP patterns were observed in 'Ruby Red' and the sweet oranges, which was explainable by their genetic proximity (Gloria et al., 2000).

The DNA samples from many 'Ruby Red' + irradiated 'Itaboraí' and 'Ruby Red' + irradiated 'Succari' shoots were analyzed. Polymorphisms were observed with different primer combinations. The fusion which led to more plants was the IOA-20 min 'Ruby Red' + 'Succari' 80 Gy. This treatment yielded 39 plantlets and many other shoots were prone to develop in $1 / 2$ NAA B + . Samples from this fusion combination were analyzed by flow cytometry analysis and were all tetraploid (Table 1). Such hybrids have great potential. Grapefruits expressing the higher total soluble solids (TSS) content of 'Succari' would be very interesting for the market, for both fresh and juice production. The tetraploid plants may also be used as breeding parents in interploid crosses. Such hybrids would hardly be obtained by sexual hybridization because both species are highly apomitic and polyembryony impairs creation of large segregating populations for selection. To date, few citrus symmetric somatic hybrids with this combination have been obtained (Grosser \& Gmitter Junior, 1990). IOA-20 min 'Ruby Red' or 'Succari' 80 Gy non-fused protoplasts (control treatment) did not develop, confirming, hence, their hybrid state, and validating the use of irradiation treatment for donor and IOA for recipient parents to accomplish inactivation of the two genomes as applied in this work.

AFLP analyses were performed more than once, using different primer combinations and polymorphisms were evident. Sample of an aneuploid plantlet (Ruby Red + Itaboraí $100 \mathrm{~Gy}$ ) presented polymorphisms with three different primer combinations tested, MseI-CT plus EcoRI-ACA, MseI-CT plus EcoRI-ACT and MseI-CA plus EcoRI-AGG. Samples from tetraploid plantlets also showed polymorphism with different primer combinations as follows: the MseI-CT plus EcoRI-ACA primer combination showed polymorphisms for two plants from 'Ruby Red' + 'Succari' 100 Gy treatment, for one from 'Ruby Red' + 'Itaboraí' 100 Gy sample, and for 17 from IOA-20 min 'Ruby Red' + 'Succari' 80 Gy treatment. The MseI-CAA plus EcoRI-ACA primer combination showed polymorphisms for one plant from IOA-20 min 'Ruby Red' + 'Succari' 30 Gy treatment, for one from IOA-15 min 'Ruby Red' + 'Itaboraí' 30 Gy

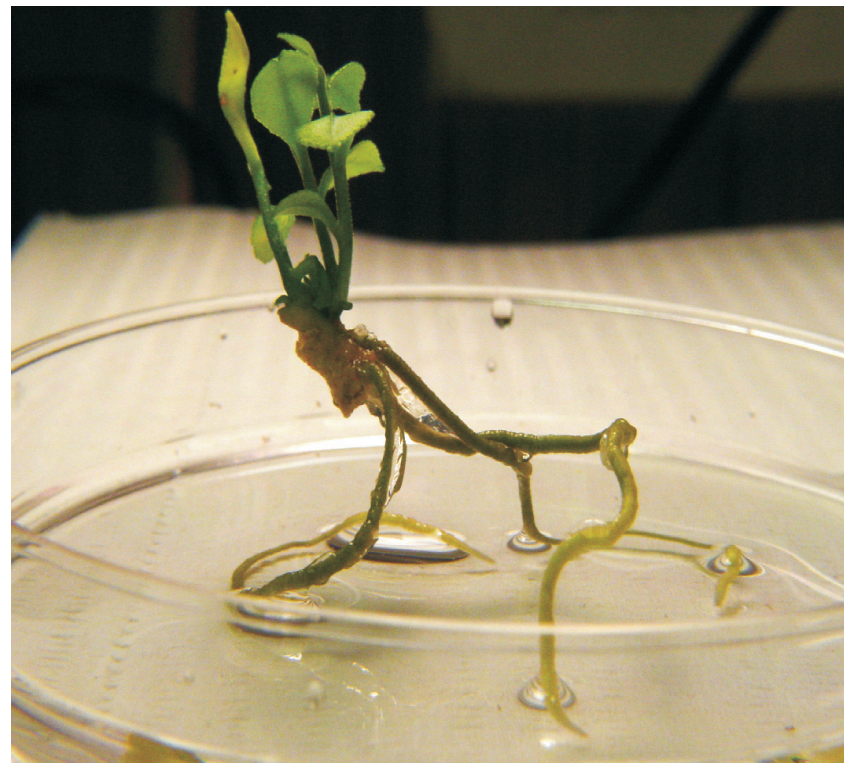

Figure 3. Rooted IOA-treated 'Ruby Red' + 80 Gy irradiated 'Succari' asymmetric hybrid. 
treatment, for four from IOA-20 min 'Ruby Red' + 'Succari' 80 Gy treatment and for two from 'Ruby Red' + 'Itaboraí' non-irradiated non-IOA-treated fusions.

The MseI-CT plus EcoRI-ACT primer combination showed polymorphisms in one 'Ruby Red' + 'Succari' 100 Gy, one in 'Ruby Red' + 'Itaboraí' 100 Gy sample and 12 in IOA-20 min 'Ruby Red' + 'Succari' 80 Gy treatments.

The MseI-CA plus EcoRI-AGG primer combination showed polymorphisms in one IOA-20 min 'Ruby Red'
+ 'Succari' 80 Gy treatment sample, one in IOA-15 min 'Ruby Red' + 'Itaboraí' 30 Gy treatment sample, one in 'Ruby Red' + 'Itaboraí' 100 Gy treatment sample and two 'Ruby Red' + 'Itaboraí' normal fusions.

The MseI-CA plus EcoRI-ACG and MseI-CT plus EcoRI-ACG primer combinations showed polymorphisms for the treatment IOA-20 $\mathrm{min}$ 'Ruby Red' + 'Succari' 80 Gy for six and four plants, respectively. Plants were tested by flow cytometry and found to be tetraploids (Table 1).

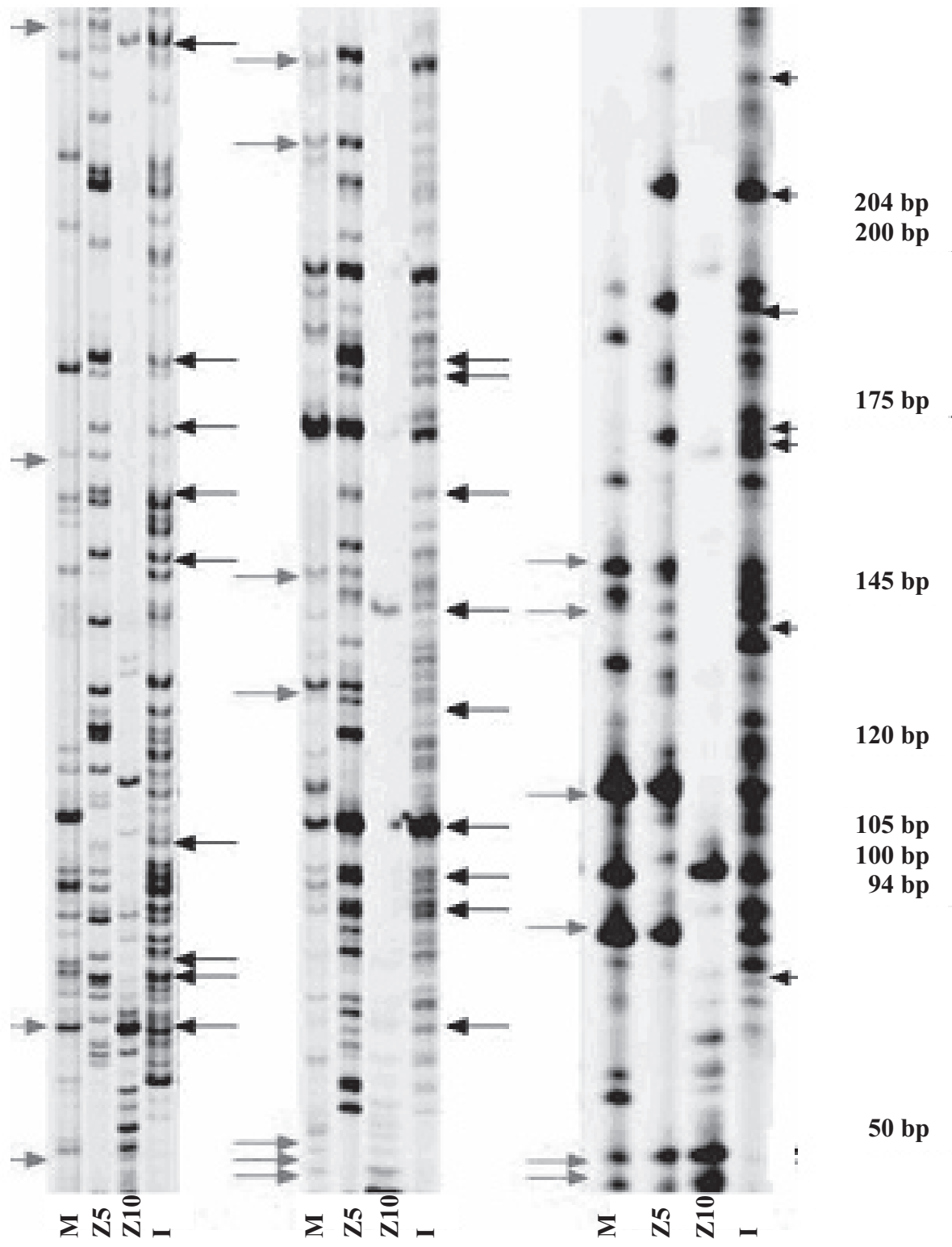

Figure 4. 'Murcott' (M) and sweet orange 'Itaborai' (I) parents and complementary parental band morphology of Z5 (IOA-15 min 'Itaborai' + 'Murcott' 50 Gy) and Z10 (IOA-20 min 'Murcott' + 'Natal' 100 Gy) with MseI-CT plus EcoRI-ACT, $M s e \mathrm{I}-\mathrm{AC}$ plus EcoRI-ACT and MseI-CAA plus EcoRI-AGG primer combinations. 


\section{Conclusions}

1. Combination of gamma irradiation with iodoacetamide is efficient for production and selection of asymmetric somatic hybrids.

2. The produced hybrids have great potential to be used as scions or as tetraploid parents in interploid crossings.

\section{Acknowledgements}

To Dr. Jude W. Grosser, University of Florida, for the supply of suspension cells from ovule-derived embryogenic callus, and for flow cytometry analysis; to Coordenação de Aperfeiçoamento de Pessoal de Nível Superior (CAPES), for a Fulbright scholarship to the first author.

\section{References}

ARUNYANART, S.; SOONTRONYATARA, S. Mutation induction by gamma and X-ray irradiation in tissue cultured lotus. Plant Cell Tissue and Organ Culture, v.70, p.119-122, 2002.

BONNEMA, A.B.; O'CONNELL, M.A. Analysis of fertility of tomato cybrids with $L$. pennellii mitochondrial DNA. Report of the Tomato Genetics Cooperative, v.40, p.7, 1990.

CALIXTO, M.C.; MOURÃO FILHO, F. de A.A.; MENDES, B.M.J.; VIEIRA, M.L.C. Somatic hybridization between Citrus sinensis (L.) Osbeck and C. grandis (L.) Osbeck. Pesquisa Agropecuária Brasileira, v.39, p.721-724, 2004.

CROWDER, A.J.; LANDGREN, C.R.; ROCKWOOD, L.L. Cultivar differences in starch content and protoplast yields from root cortical explants of Pisum sativum. Physiologia Plantarum, v.46, p.85-88, 1979.

DAVIES, F.S.; ALBRIGO, L.G. Citrus. Wallingford: CAB, 1994.

DERKS, F.H.M.; HALL, R.D.; COLIJNHOOYMANS, C.M. Effect of gamma-irradiation on protoplast viability and chloroplast DNA damage in Lycopersicon peruvianum with respect to donor recipient protoplast fusion. Environmental and Experimental Botany, v.32, p.255-264, 1992.

EPSTEIN, D.L.; HASHIMOTO, J.M.; ANDERSON, P.J.; GRANT, W.M. Effect of iodoacetamide perfusion on outflow facility and metabolism of the trabecular meshwork. Association for Research in Vision and Ophthalmology, v.20, p.625-631, 1981.

FANG, K.F.; ZHANG, L.Y.; LIN, J.X. A rapid, efficient method for the mass production of pollen protoplasts from Pinus bungeana Zucc. ex Endl. and Picea wilsonii Mast. Flora, v.201, p.74-80, 2006.

FURUTA, H.; SHINOYAMA, H.; NOMURA, Y.; MAEDA, M.; MAKARA, K. Production of intergeneric somatic hybrids of chrysanthemum [Dendranthema x grandiflorum (Ramat.) Kitamura] and wormwood (Artemisia sieversiana J.F. Ehrh. ex. Willd) with rust (Puccinia horiana Henning) resistance by electrofusion of protoplasts. Plant Science, v.166, p.695-702, 2004.
GE, T.M.; LIN, X.H.; QIN, F.L.; YU, S.W.; YU, Y.J. Protoplast electrofusion between common wheat (Triticum aestivum L.) and Italian ryegrass (Lolium multiflorum Lam.) and regeneration of mature cybrids. In vitro Cellular \& Developmental Biology. Plant, v.42, p.179-187, 2006.

GLORIA, F.J.M. da; MOURÃO FILHO, F. de A.A.; MENDES, B.M.J. Plant regeneration from protoplast of Brazilian citrus cultivars. Pesquisa Agropecuária Brasileira, v.35, p.727-732, 2000.

GROSSER, J.W.; GMITTER JUNIOR, F.G. Applications of somatic hybridization and cybridization in crop improvement, with citrus as a model. In vitro Cellular \& Developmental Biology. Plant, v.41, p.220-225, 2005.

GROSSER, J.W.; GMITTER JUNIOR, F.G. Protoplast fusion and citrus improvement. Plant Breeding Reviews, v.8, p.339-374, 1990.

HARTMANN, H.T.; KESTER, D.E.; DAVIES JUNIOR, F.T.; GENEVE, R.L. Hartmann and kester's plant propagation: principles and practices. $7^{\text {th }}$ ed. Upper Saddle River: Prentice-Hall International, 1997. 880p.

LIU, J.H.; DENG, X.X. Regeneration and analysis of citrus interspecific mixoploid hybrid plants from asymmetric somatic hybridization. Euphytica, v.125, p.13-20, 2002.

LOUZADA, E.S.; DEL RIO, H.S.; XIA, D.; MORAN-MIRABAL, J.M. Preparation and fusion of Citrus sp. microprotoplasts. Journal of the American Society for Horticultural Science, v.127, p.484-488, 2002.

MIRANDA, M.; MOTOMURA, T.; IKEDA, F.; OHGAWARA, T.; SAITO, W.; ENDO, T.; OMURA, M.; MORIGUCHI, T. Somatic hybrids obtained by fusion between Poncirus trifoliata $(2 \mathrm{x})$ and Fortunella hindsii (4x) protoplasts. Plant Cell Reports, v.16, p.401-405, 1997.

OLLITRAULT, P.; DAMBIER, D.; FROELICHER, Y.; CARREEL, F.; D'HONT, A.; LURO, F.; BRUYERE, S.; CABASSON, C.; LOTFY, S.; JOUMMA, A.; VANEL, F.; MADDI, F.; TREANTON, K.; GRISONI, M. Somatic hybridization potential for citrus germplasm utilization. Agricultures, v.3, p.223-236, 2000.

PAPADAKIS, A.K.; ROUBELAKIS-ANGELAKIS, K.A. Oxidative stress could be responsible for the recalcitrance of plant protoplasts. Plant Physiology and Biochemistry, v.40, p.549-559, 2002.

RASMUSSEN, J.O.; LOSSL, A.; RASMUSSEN, O.S. Analysis of the plastome and chondriome origin in plants regenerated after asymmetric Solanum spp. protoplast fusions. Theoretical and Applied Genetics, v.101, p.336-343, 2000.

TIAN, D.; NIU, C.; ROSE, R.J. DNA transfer by highly asymmetric somatic hybridization in Medicago truncatula (+) Medicago rugosa and Medicago truncatula $(+)$ Medicago scutellata. Theoretical and Applied Genetics, v.104, p.9-16, 2002.

VARDI,A.;ARZEE-GONEN,P;;FRYDMAN-SHANI,A.;BLEICHMAN, S.; GALLUN, E. Protoplast-fusion-mediated transfer of organelles from Microcitrus into Citrus and regeneration of novel alloplasmic trees. Theoretical and Applied Genetics, v.78, p.741-747, 1989.

VAROTTO, S.; NENZ, E.; LUCCHIN, M.; PARRINI, P. Production of asymmetric somatic hybrid plants between Cichorium intybus L. and Helianthus annuus L. Theoretical and Applied Genetics, v.102, p.950-956, 2001.

Received on January 6, 2009 and accepted on April 30, 2009 